\title{
Studies on $\mathrm{Pd} / \mathrm{NiFe}_{2} \mathrm{O}_{4}$ catalyzed ligand-free Suzuki reaction in aqueous phase: synthesis of biaryls, terphenyls and polyaryls
}

\author{
Sanjay R. Borhade and Suresh B. Waghmode ${ }^{*} \S$
}

\section{Full Research Paper}

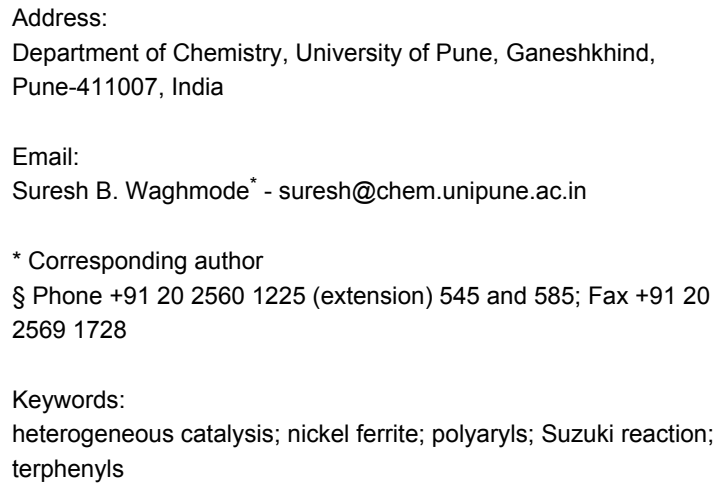

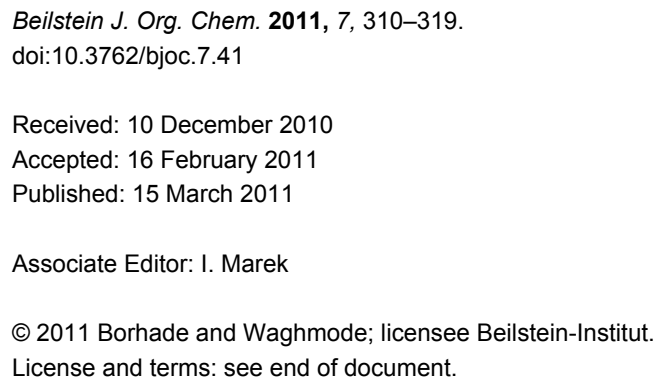

\begin{abstract}
Palladium supported on nickel ferrite $\left(\mathrm{Pd} / \mathrm{NiF}_{2} \mathrm{O}_{4}\right)$ was found to be a highly active catalyst for the Suzuki coupling reaction between various aryl halides and arylboronic acids. The reaction gave excellent yields (70-98\%) under ligand free conditions in a 1:1 DMF/ $\mathrm{H}_{2} \mathrm{O}$ solvent mixture, in short reaction times (10-60 min). The catalyst could be recovered easily by applying an external magnetic field. The polyaryls were similarly synthesized.
\end{abstract}

\section{Introduction}

Recently, transition metal catalyzed cross-coupling protocols have generated immense interest owing to their versatile applications in organic synthesis [1-4]. The Pd catalyzed Suzuki reaction between aryl halides with arylboronic acids is one of the most important and powerful methods for the construction of biaryls and polyaryls due to its compatibility towards a wide range of functional groups on both partners [5-10]. The resulting Suzuki products have found numerous applications in the synthesis of natural products, pharmaceutical intermediates, pesticides, advanced materials and liquid crystals [8-10]. These applications, in turn, have led to the production of biaryls and polyaryls on the industrial scale [11]. The Suzuki reaction is usually performed with homogeneous palladium catalysts in the presence of phosphorous ligands. Efforts have been made to enhance the catalytic activity by the use of various ligands containing nitrogen or sulfur, as well as phosphines, salen and $N$-heterocyclic carbenes in traditional organic solvents [12-19]. However, the problems associated with catalyst separation, 
poisoning, and product contamination, have led to researchers investigating heterogeneous routes [20,21]. In the last few decades, more attention has been given to overcome these problems by employing a number of heterogeneous palladium systems, such as palladium supported on a variety of support materials (e.g., carbon, metal oxides, zeolites, clays, polymers, diatomite and graphite oxide) as well as in ionic liquids [22-32] In addition, efforts were also made to replace the environmentally harmful organic solvents by eco-friendly solvents such as water to make the scale up procedure economical and viable for industrial applications [33-37]. This has led to the use of water soluble ligands, additives and reusable heterogeneous supported $\mathrm{Pd}$ catalysts $[38,39]$. However, the limited availability of water soluble aryl halides and the limited scope of the Suzuki reaction under ligand free conditions in the absence of additives thus faced with these limitations requires a fresh approach to carry out the Suzuki reaction.

Recently, the use of Pd supported on surface-modified nano $\mathrm{NiFe}_{2} \mathrm{O}_{4}$ catalyst for the Heck and Suzuki reactions was demonstrated [40]. The most important paradigm of this reaction is the easy removal of catalyst from the reaction mixture by employing an external magnetic field. We recently reported the filtration-free magnetically separable $\mathrm{Pd} / \mathrm{NiFe}_{2} \mathrm{O}_{4}$ catalyst for the Heck reaction [41]. Herein, we report the successful exploitation of the magnetically recoverable Pd supported on $\mathrm{NiFe}_{2} \mathrm{O}_{4}$ catalyst for the Suzuki reaction with various substrates and the optimization of reaction conditions under ligand free heterogeneous conditions in an aqueous phase. Moreover, to the best of our knowledge, this is the first report describing the synthesis of polyaryls under these reaction conditions and with this catalyst.

\section{Results and Discussion}

Nickel ferrite samples were synthesized as reported earlier [42]. Loading of Pd on nickel ferrite was carried out by wet impregnation and subsequently reduced by the continuous flow of hydrogen gas [43]. The scanning electron microscope image shows that particle size of the catalyst is $\sim 100$ to $300 \mathrm{~nm}$ (Supporting Information File 1). The X-ray photoemission spectra confirms the formation of metallic $\operatorname{Pd}(0)$ particles, the binding energy values were 335.3 and $340.5 \mathrm{eV}$ for $\operatorname{Pd}\left(3 \mathrm{~d}_{5 / 2}\right)$ and $\operatorname{Pd}\left(3 \mathrm{~d}_{3 / 2}\right)$ core levels, respectively (Supporting Information File 1). The catalyst is stable under the employed reaction conditions, which was confirmed by the X-ray diffraction pattern of fresh and spent catalyst (Supporting Information File 1). The coupling of iodobenzene with phenylboronic acid was studied as the model reaction in air and the reaction conditions were systematically optimized. The reaction was carried out using $\mathrm{Na}_{2} \mathrm{CO}_{3}$ as the base in the presence of $0.1 \mathrm{~mol} \% \mathrm{Pd}$ at $90{ }^{\circ} \mathrm{C}$.
We initially studied the effect of solvents and the addition of water as the co-solvent on the Suzuki coupling reaction (Table 1). These results indicated that the reaction in polar aprotic solvents such as dimethylformamide (DMF), dimethylacetamide (DMA), $N$-methylpyrrolidin-2-one (NMP) and dimethylsulfoxide (DMSO) showed only $34-50 \%$ conversion after $2 \mathrm{~h}$ (Table 1, entries 1-4). The reaction in ethereal, alcoholic, and non-polar solvents was sluggish (Table 1, entries 5-10). However, the addition of water as co-solvent to the polar aprotic solvents greatly improved the rate of reaction. The addition of water to DMF led to a very rapid increase in the reaction rate: The reaction being completed after 5 and 10 min when the ratio of DMF and water was $1: 1$ and 3:2, respectively (Table 1, entries 13-18). The results suggested that, the ratio of water to DMF played an important role in the $\mathrm{Pd} / \mathrm{NiFe}_{2} \mathrm{O}_{4}$ catalyzed Suzuki reaction.

Table 1: The effect of different solvents on the Suzuki coupling reac-
tion ${ }^{\mathrm{a}}$.

aReaction conditions: iodobenzene ( $1 \mathrm{mmol})$, phenylboronic acid (1.2 mmol), $\mathrm{Na}_{2} \mathrm{CO}_{3}(2 \mathrm{mmol}), \mathrm{Pd} / \mathrm{NiFe}_{2} \mathrm{O}_{4}(0.1 \mathrm{~mol} \%)$ and $4 \mathrm{~mL}$ of solvent at $90^{\circ} \mathrm{C}$

${ }^{\mathrm{b}}$ Conversions were determined by GC $\left(\Delta_{\mathrm{rel}}= \pm 5 \%\right)$.

'Tetrabutylammonium bromide was added. 
Among the various bases studied, inorganic bases were superior to organic bases such as triethylamine (TEA) and tributylamine (TBA) which may be due to partial inhomogenity in the aqueous phase. As the basicity of alkali carbonate increases, the time for completion of the reaction increases (Table 2, entries 4-6). $\mathrm{Na}_{2} \mathrm{CO}_{3}$ was found to be the best base (Table 2, entry 4) Sodium hydroxide did not appear to be an effective base under these reaction conditions (Table 2 , entry 3 ).

Table 2: The effect of various bases on the Suzuki coupling reactiona.

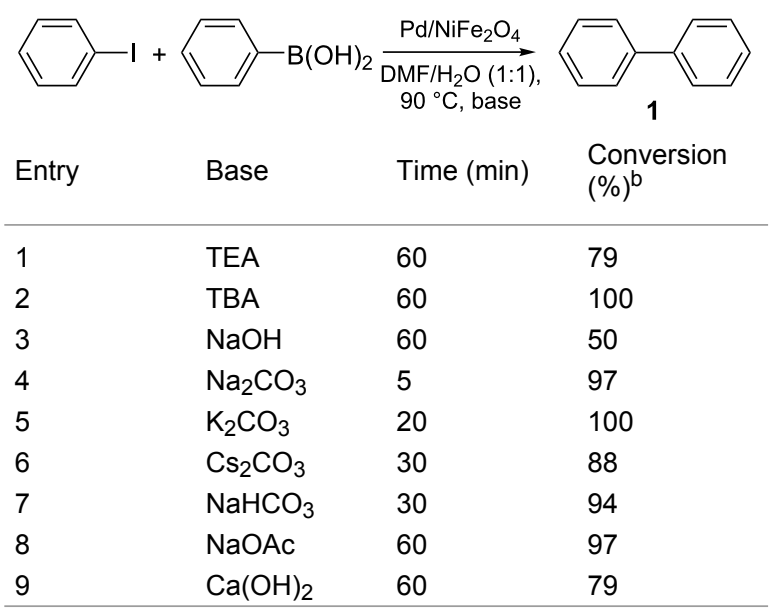

aReaction conditions: iodobenzene $(1 \mathrm{mmol})$, phenylboronic acid $(1.2 \mathrm{mmol})$, base $(2 \mathrm{mmol}), \mathrm{Pd} / \mathrm{NiFe}_{2} \mathrm{O}_{4}(0.1 \mathrm{~mol} \%)$ and $4 \mathrm{~mL}$ of $1: 1$ $\mathrm{DMF} / \mathrm{H}_{2} \mathrm{O}$ at $90^{\circ} \mathrm{C}$.

${ }^{\mathrm{b}}$ Conversions were determined by $\mathrm{GC}\left(\Delta_{\mathrm{rel}}= \pm 5 \%\right)$.

The effect of temperature on the activity of $\mathrm{Pd} / \mathrm{NiFe}_{2} \mathrm{O}_{4}$ catalyst was studied in the range $30-100{ }^{\circ} \mathrm{C}$. Table 3 shows that the percentage conversion increased with temperature. The reaction can be performed at room temperature, but the reaction time was significantly increased (Table 3 , entry 1 ).

The effect of Pd concentration on the Suzuki reaction was also studied. A graph depicting conversion versus time showed that the catalytic activity increased with Pd content (Supporting Information File 1). The reaction was complete within $5 \mathrm{~min}$, with excellent conversion using $0.5 \mathrm{~mol} \% \mathrm{Pd}$. A decrease in Pd concentration from 0.25 to $0.1 \mathrm{~mol} \%$ did not influence the rate of reaction to any great extent. However, when the Pd concentration was lowered to $0.005 \mathrm{~mol} \%$, the catalyst still functioned very well, but the conversion was too low to be of practical use.

Using the preliminary optimized reaction conditions, we explored the general applicability of $\mathrm{Pd} / \mathrm{NiFe}_{2} \mathrm{O}_{4}$ catalyst with various boronic acids and aryl halides containing electron with-
Table 3: The effect of various temperatures on the Suzuki coupling reactiona.

\begin{tabular}{llll} 
Entry & Temperature & $\substack{\text { Time (min) } \\
\mathrm{Na}_{2} \mathrm{CO}_{3}, \text { temp }}$ & $\begin{array}{l}\text { Conversion } \\
(\%)^{\mathrm{b}}\end{array}$ \\
\hline 1 & 30 & 360 & 88 \\
2 & 50 & 120 & 86 \\
3 & 70 & 60 & 98 \\
4 & 80 & 10 & 99 \\
5 & 90 & 5 & 97 \\
6 & 100 & 5 & 99
\end{tabular}

aReaction conditions: iodobenzene $(1 \mathrm{mmol})$, phenylboronic acid (1.2 mmol), base $(2 \mathrm{mmol}), \mathrm{Pd} / \mathrm{NiFe}_{2} \mathrm{O}_{4}(0.1 \mathrm{~mol} \%)$ and $4 \mathrm{~mL}$ of $1: 1$ $\mathrm{DMF} / \mathrm{H}_{2} \mathrm{O}$ at various temperatures.

${ }^{\text {b } C o n v e r s i o n s ~ w e r e ~ d e t e r m i n e d ~ b y ~ G C ~}\left(\Delta_{\text {rel }}= \pm 5 \%\right)$.

drawing or donating substituents (Table 4). The $\mathrm{Pd} / \mathrm{NiFe}_{2} \mathrm{O}_{4}$ catalyzed Suzuki reaction tolerated a wide range of functional groups such as $\mathrm{NO}_{2}, \mathrm{CHO}, \mathrm{Me}, \mathrm{Cl}, \mathrm{OMe}, \mathrm{OH}, \mathrm{NH}_{2}$, and Ac. The aryl iodides and electron deficient aryl bromides showed excellent reactivity with phenyl- and 3-(hydroxymethyl)phenylboronic acid and led to the expected products in high yields within short reaction times. Bromobenzene and electron rich aryl bromides required a higher loading of palladium $(1.0 \mathrm{~mol} \%)$ to give comparable results. Both electron rich and electron deficient arylboronic acids gave biaryl products in good to excellent yields. Heterocyclic boronic acids required longer reaction times compared to arylboronic acids, probably as a result of strong coordination of the heterocyclic nitrogen with Pd metal. Ortho substituted aryl iodides required slightly longer reaction times to give the corresponding biaryls. The coupling of 4-chloroiodobenzene with phenylboronic acid gave exclusively 4-chlorobiphenyl in good yield. However, under these reaction conditions, selective monoarylation of 4-bromoiodobenzene did not occur even with a stoichiometric amount of phenylboronic acid. The comparatively less reactive chlorobenzene did not undergo satisfactory conversion even after $24 \mathrm{~h}$ (Table 4, entry 35). Whereas, activated aryl chlorides gave the coupling product in moderate yields after $24 \mathrm{~h}$ (Table 4, entries 33, 34).

Recently, terphenyls have attracted attention due to their wide range of significant biological applications including potent immunosuppressant, neuroprotective, antithrombotic, anticoagulant and cytotoxic activities [44-47]. Polyphenyls are also an important structural element in liquid crystals and fluorescent compounds [48-52]. Terphenyls have been previously synthesized by the reaction of aryl- or benzylzinc reagents with func- 
Table 4: Suzuki cross coupling reaction of aryl halides with arylboronic acida

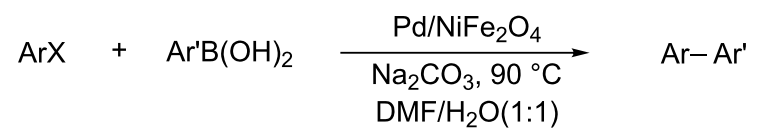

\begin{tabular}{|c|c|c|c|c|c|}
\hline Entry & Aryl halide & Arylboronic acid & Product & Time (min) & Yield $^{\mathrm{b}}(\%)$ \\
\hline 1 & & & 1 & 5 & 97 \\
\hline 2 & & & 2 & 15 & 92 \\
\hline 3 & & & 3 & 15 & 96 \\
\hline 4 & & & 4 & 20 & 91 \\
\hline 5 & & & 5 & 60 & 78 \\
\hline 6 & & & 6 & 60 & 72 \\
\hline 7 & & & 1 & 60 & 69 \\
\hline $8^{c}$ & & & 1 & 30 & 98 \\
\hline $9^{c}$ & & & 2 & 45 & 95 \\
\hline $10^{c}$ & & & 3 & 30 & 92 \\
\hline $11^{\mathrm{c}}$ & & & 4 & 35 & 89 \\
\hline $12^{c}$ & & $R$ & 5 & 60 & 68 \\
\hline $13^{c}$ & & & 6 & 60 & 76 \\
\hline $14^{\mathrm{c}}$ & & & 7 & 150 & 78 \\
\hline $15^{c}$ & & & 8 & 120 & 81 \\
\hline 16 & & & 9 & 45 & 80 \\
\hline 17 & & & 10 & 60 & 75 \\
\hline
\end{tabular}


Table 4: Suzuki cross coupling reaction of aryl halides with arylboronic acid ${ }^{\mathrm{a}}$. (continued)

18

19

20

21

22

23

24

25

26

27

28

29

30

31

32

$33^{d}$

$34^{d}$

$35^{d}$<smiles>COc1ccccc1I</smiles><smiles>COc1ccc(I)cc1</smiles><smiles>COc1ccc(I)cc1</smiles><smiles>Cc1ccc(I)cc1</smiles><smiles>Cc1ccc(I)cc1</smiles>
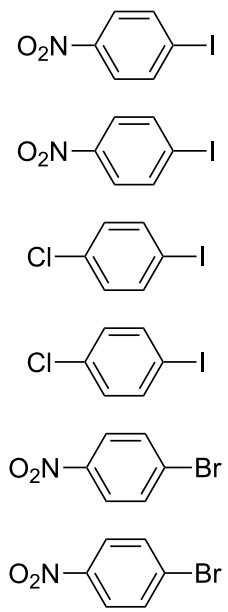<smiles>O=Cc1ccc(Br)cc1</smiles><smiles>[C]#Cc1ccc(Br)cc1</smiles><smiles>COc1ccc(Br)cc1</smiles><smiles>COc1ccc(Br)cc1</smiles>

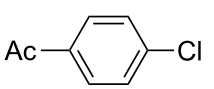<smiles>O=[N+]([O-])c1ccc(Cl)cc1</smiles><smiles>Oc1ccccc1</smiles><smiles>COc1cccc(CO)c1</smiles><smiles>Oc1ccccc1</smiles><smiles>OCc1cccc(Br)c1</smiles><smiles></smiles><smiles>OCc1cccc(Br)c1</smiles><smiles>Oc1ccccc1</smiles><smiles>OCc1cccc(Br)c1</smiles><smiles>Oc1ccccc1</smiles><smiles>Oc1ccccc1</smiles><smiles>Oc1ccccc1</smiles><smiles>OCc1cccc(Br)c1</smiles><smiles>Oc1ccccc1</smiles><smiles>COc1ccccc1</smiles><smiles>Oc1ccccc1</smiles>

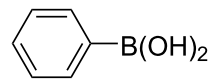

13

14

15

11

12

20

30

30

30

15

15

15

15

15

15

30

30

24

24

24
86

96

94

97

96

94

96

89

93

95

95

88

96

85

94

23

6

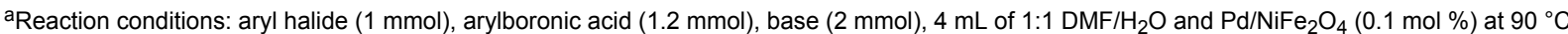
${ }^{b}$ After purification by flash silica gel chromatography.

$\mathrm{c}_{1} \mathrm{~mol} \%$ of $\mathrm{Pd} / \mathrm{NiFe}_{2} \mathrm{O}_{4}$ used for entries 8-15.

${ }^{\mathrm{d}} 0.25 \mathrm{~mol} \%$ of $\mathrm{Pd} / \mathrm{NiFe}_{2} \mathrm{O}_{4}$ used at $105^{\circ} \mathrm{C}$ and time reported in $\mathrm{h}$ for entries $33-35$. 
tionalized biphenyl nonaflates [53], Grignard reagents with dihalobenzenes [54-56]: Other methods give poor yields. The Suzuki cross coupling protocol has been used for the synthesis of terphenyls and polyaryls using $\mathrm{Pd}(\mathrm{OAc})_{2}$ or $\mathrm{Pd}\left(\mathrm{PPh}_{3}\right)_{4}$ with or without ligands in homogeneous medium [57-60]. Although, these authors have reported good yields of terphenyls and polyaryls, the fact that the precious palladium catalyst is nonrecoverable renders these processes commercially undesirable. The first use of heterogeneous Pd-modified silica catalyst for consecutive Suzuki reactions was reported by Clark et al. for the synthesis of terphenyls as well as polyaryls using di- and tribromoarenes with phenylboronic acids in $o$-xylene as solvent at $120^{\circ} \mathrm{C}$ for $20 \mathrm{~h}$ under a $\mathrm{N}_{2}$ atmosphere [61]. We have studied the usefulness of $\mathrm{Pd} / \mathrm{NiFe}_{2} \mathrm{O}_{4}$ catalyst for the synthesis of terphenyls and polyaryls in a single step under the optimized reaction conditions. The results thus obtained are summarized in Table 5. The reactions were performed by using $1.0 \mathrm{~mol} \%$ of $\mathrm{Pd}$ at $90{ }^{\circ} \mathrm{C}$ and 3.5 equiv of arylboronic acid in $1: 1 \mathrm{DMF} / \mathrm{H}_{2} \mathrm{O}$ solvent for $2 \mathrm{~h}$. The reaction between various di- and trihalo aryls with phenyl- and 3-(hydroxymethyl)phenylboronic acids led to multiple coupling products in good to excellent yields (Table 5, entries 1-16).

The feasibility of recycling the $\mathrm{Pd} / \mathrm{NiFe}_{2} \mathrm{O}_{4}$ was examined (Supporting Information File 1). The recycling experiment was performed on the model reaction (iodobenzene with phenylboronic acid). After completion of the reaction the catalyst was removed by applying an external magnet and washed with dichloromethane and water several times. The oven dried $\left(100{ }^{\circ} \mathrm{C}\right)$ catalyst was then used for the next run. The $\mathrm{Pd} /$ $\mathrm{NiFe}_{2} \mathrm{O}_{4}$ catalyst exhibited only a marginal change in the catalytic activity and required a longer reaction time to achieve the similar conversion after the fourth cycle.

In the literature, several mechanisms have been considered for the interaction of the Pd catalyst with the substrate and inter-

Table 5: Suzuki cross coupling reaction of di- and trihaloaryls with arylboronic acida

1<smiles>Brc1ccccc1I</smiles>

2<smiles>Brc1ccccc1I</smiles>

3<smiles>Brc1ccccc1Br</smiles>

4<smiles>Brc1ccccc1Br</smiles>

5<smiles>Brc1ccc(I)cc1</smiles>

6

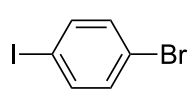

Arylboronic acid<smiles></smiles><smiles>OCc1cccc(Br)c1</smiles><smiles>COc1ccccc1</smiles><smiles>OCc1cccc(Br)c1</smiles><smiles></smiles><smiles>OCc1cccc(Br)c1</smiles>

Product

Yield $^{b}$<smiles>c1ccc(-c2ccccc2-c2ccccc2)cc1</smiles><smiles>OCc1cccc(-c2ccccc2-c2cccc(CO)c2)c1</smiles><smiles>c1ccc(-c2ccccc2-c2ccccc2)cc1</smiles><smiles>OCc1cccc(-c2ccccc2-c2cccc(CO)c2)c1</smiles><smiles>c1ccc(-c2ccc(-c3ccccc3)cc2)cc1</smiles>

24<smiles>[R6]OCc1cccc(-c2cccc(-c3cccc(CO)c3)c2)c1</smiles>

88

76 
Table 5: Suzuki cross coupling reaction of di- and trihaloaryls with arylboronic acid ${ }^{\mathrm{a}}$. (continued)

7<smiles>Ic1cccc(I)c1</smiles>

8<smiles>Ic1cccc(I)c1</smiles>

9<smiles>Brc1cccc(Br)c1</smiles>

10<smiles>Brc1cccc(Br)c1</smiles>

11<smiles>Brc1cccc(I)c1</smiles>

12<smiles>Brc1cccc(I)c1</smiles>

13<smiles>Brc1ccc(Br)cc1</smiles>

14<smiles>Brc1ccc(Br)cc1</smiles>

15<smiles>Brc1cc(Br)cc(Br)c1</smiles>

16<smiles>Brc1cc(Br)cc(Br)c1</smiles><smiles>OCc1cccc(Br)c1</smiles><smiles>Oc1ccccc1</smiles><smiles>OCc1cccc(Br)c1</smiles><smiles></smiles><smiles>OCc1cccc(Br)c1</smiles><smiles></smiles><smiles>OCc1cccc(Br)c1</smiles><smiles>[Mg]Oc1ccccc1</smiles><smiles></smiles><smiles>OCc1cccc(Br)c1</smiles><smiles>c1ccc(-c2cccc(-c3ccccc3)c2)cc1</smiles><smiles>OCc1cccc(-c2cccc(-c3cccc(CO)c3)c2)c1</smiles>

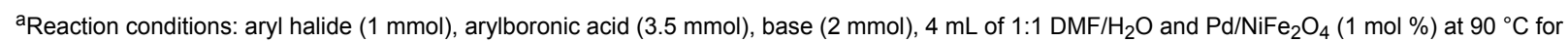
$2 \mathrm{~h}$.

${ }^{b}$ After purification by flash silica gel chromatography. 
mediates [62]. It has become more and more accepted that the $\mathrm{Pd}$ in solution as a colloid or complexed is the true catalytically active species for the heterogeneous catalyzed reaction $[28,62]$. We believe that, the nickel ferrite activates the Pd surface which helps better desorption and leads to faster formation of colloids or complexes in the solution, and that the palladium is redeposited onto the support or Pd clusters on completion of the reaction. Thus, $\mathrm{Pd} / \mathrm{NiFe}_{2} \mathrm{O}_{4}$ acts like a reservoir for the dissolved $\mathrm{Pd}$ species, in a different phase from that of reactants and products. To confirm this assumption, we performed the model reaction between iodobenzene and phenylboronic acid. After the reaction was complete, $\mathrm{Pd} / \mathrm{NiFe}_{2} \mathrm{O}_{4}$ catalyst was removed from the hot reaction mixture by applying an external magnet and the clear solution filtered to remove any dispersed particles. To the clear filtrate, the appropriate amounts of new substrates, i.e., 4-iodotoluene, phenylboronic acid and base was added. The composition of the reaction mixture was analyzed by GC, the amount of 4 -iodotoluene was set to $100 \%$ and the reaction was performed under the identical reaction conditions. It was observed that $54 \%$ of 4 -iodotoluene was converted to the corresponding biaryl after $60 \mathrm{~min}$ and the Pd content detected in the filtrate was $2.3 \mathrm{ppm}$ based on AAS analysis. In another set of experiment, we heated the freshly prepared $\mathrm{Pd} / \mathrm{NiFe}_{2} \mathrm{O}_{4}$ catalyst at $90{ }^{\circ} \mathrm{C}$ in $1: 1 \mathrm{DMF} / \mathrm{H}_{2} \mathrm{O}$ solvent for $30 \mathrm{~min}$. After separating the hot solid catalyst, the clear filtrate was mixed with the appropriate amounts of iodobenzene, phenylboronic acid and $\mathrm{Na}_{2} \mathrm{CO}_{3}$ and the Suzuki reaction carried out at $90{ }^{\circ} \mathrm{C}$. After heating for $60 \mathrm{~min}$, only $29 \%$ iodobenzene was converted to biphenyl and $1.1 \mathrm{ppm}$ of Pd was detected in the solution. This suggested that the oxidative addition of the iodobenzene to the surface $\operatorname{Pd}(0)$ converted $\operatorname{Pd}(0)$ into $\operatorname{Pd}(\mathrm{II})$ and resulted in the leaching of a certain amount of palladium particles into the solution. The experimental results showed that the leaching of palladium was required for this sustaining catalytic activity and nickel ferrite supported palladium provides the source of palladium in the process.

\section{Conclusion}

In summary, we have extensively studied the $\mathrm{Pd} / \mathrm{NiFe}_{2} \mathrm{O}_{4}$ catalyst which showed high catalytic activity in the Suzuki reaction in aqueous DMF in short reaction times. The salient features of the present methodology are that it is ligand free, heterogeneous, uses water as a co-solvent and requires no additives. Moreover, the method can be extended to the synthesis of various polyaryls in a single step with high yield and selectivity under aerobic conditions in aqueous solvents. The $\mathrm{Pd} / \mathrm{NiFe}_{2} \mathrm{O}_{4}$ catalyst can be easily removed from the reaction mixture by applying an external magnetic field and reused several times without significant loss of catalytic activity. The studies reveal that the palladium leaching into the solution provides the catalytic site.

\section{Experimental General}

All experiments and manipulations were performed in an ambient atmosphere. All glassware was washed with acid then base and oven dried before use. The catalytic reactions were carried out in round bottom flasks equipped with a reflux condenser. The $\left[\mathrm{Pd}\left(\mathrm{NH}_{3}\right)_{4}\right](\mathrm{OAc})_{2}$, reactants and solvents were obtained from Sigma-Aldrich/Merck or Spectrochem and used as received without further purification or drying. The progress of reaction was monitored by GC (HP-5890, series II, equipped with HP-5 capillary column and a FID detector, using $\mathrm{N}_{2}$ as the carrier gas). The products were isolated by extraction with ethyl acetate and purified by silica gel (100-200) column chromatography. The isolated products were characterized by GC-MS (Shimadzu QP-5050, DB-5 column and a TCD detector with He as the carrier gas), FTIR (8400 Shimadzu), and NMR spectroscopy (Varian $300 \mathrm{MHz}$ spectrometer in $\mathrm{CDCl}_{3}$ or DMSO- $d_{6}$ with TMS as an internal standard). The Pd content was measured by Atomic Absorption Spectrophotometer (AAS), Model no: Chemito AA-201.

\section{General procedure for the synthesis of $\mathrm{NiFe}_{2} \mathrm{O}_{4}$}

The metal oxalate precursor was prepared by adding $32 \mathrm{~mL}$ of a $\mathrm{N}_{2}$ purged solution of $\mathrm{NiSO}_{4} \cdot 6 \mathrm{H}_{2} \mathrm{O}(3.0 \mathrm{~g}, 0.0114 \mathrm{~mol})$ and $\mathrm{FeSO}_{4} \cdot 7 \mathrm{H}_{2} \mathrm{O}(6.82 \mathrm{~g}, 0.0228 \mathrm{~mol})$ to the $80 \mathrm{~mL}$ of $\mathrm{N}_{2}$ purged $\left(\mathrm{COONH}_{4}\right)_{2} \cdot \mathrm{H}_{2} \mathrm{O}(3.65 \mathrm{~g}, 0.0228 \mathrm{~mol})$ with vigorous stirring. The resulting yellowish green suspension was cooled to $0{ }^{\circ} \mathrm{C}$ and the supernatant liquid decanted before filtration. The precipitate was washed with $\sim 250 \mathrm{~mL}$ distilled water and dried in an oven at $110^{\circ} \mathrm{C}$ for $1 \mathrm{~h}$. The nickel ferrite was obtained by heating the above precipitate in air for $4 \mathrm{~h}$ at $550{ }^{\circ} \mathrm{C}$ in a silica crucible in a pre-heated muffle furnace.

\section{Typical procedure for the palladium deposition onto $\mathrm{NiFe}_{2} \mathrm{O}_{4}$}

To a suspension of $\mathrm{NiFe}_{2} \mathrm{O}_{4}(1.0 \mathrm{~g})$ in absolute ethanol $(100 \mathrm{~mL}),\left[\mathrm{Pd}\left(\mathrm{NH}_{3}\right)_{4}\right](\mathrm{OAc})_{2}(0.010 \mathrm{~g})$ was added. The brownish slurry was stirred for $6 \mathrm{~h}$ at room temperature. The solvent was then evaporated under reduced pressure on rotary evaporator. The Pd-impregnated solid was dried in oven at $100{ }^{\circ} \mathrm{C}$ for $3 \mathrm{~h}$, then reduced under a continuous stream of hydrogen gas $(20 \mathrm{~mL} / \mathrm{min})$ at $200{ }^{\circ} \mathrm{C}$ for $4 \mathrm{~h}$ to give a black powder $\left(\right.$ BET surface area $=29 \mathrm{~m}^{2} / \mathrm{g}$ ).

\section{General procedure for Suzuki reaction catalyzed by $\mathrm{Pd} / \mathrm{NiFe}_{2} \mathrm{O}_{4}$}

To a $25 \mathrm{~mL}$ two neck round bottom flask attached with a reflux condenser, were added the aryl halide $(1 \mathrm{mmol})$, boronic acid (1.25 mmol), $\mathrm{Na}_{2} \mathrm{CO}_{3}(2 \mathrm{mmol})$, and $\mathrm{Pd} / \mathrm{NiFe}_{2} \mathrm{O}_{4}(0.1 \mathrm{~mol} \%)$ in $4 \mathrm{~mL} \mathrm{DMF} / \mathrm{H}_{2} \mathrm{O}(1: 1)$, and the reaction mixture heated at the appropriate temperature and duration. The reaction was moni- 
tored by gas chromatography. After the reaction was complete, the mixture was extracted with ethyl acetate three times, the combined organic extracts dried over anhydrous $\mathrm{Na}_{2} \mathrm{SO}_{4}$ and the solvent evaporated at reduced pressure. The crude products were then purified by column chromatography [hexane or hexane/ethyl acetate (9:1)] and analyzed by GC, GC-MS, IR, and NMR.

\section{Supporting Information}

Scanning electron microscope image, X-ray photoemission spectrum, X-ray powder diffraction pattern, catalytic activity of different loading of palladium over $\mathrm{NiFe}_{2} \mathrm{O}_{4}$, catalyst recycling studies and ${ }^{1} \mathrm{H}$ and ${ }^{13} \mathrm{C}$ NMR for the products 1-29.

\section{Supporting Information File 1}

Characterization data of the catalyst and of the products 1-29.

[http://www.beilstein-journals.org/bjoc/content/ supplementary/1860-5397-7-41-S1.pdf]

\section{Acknowledgements}

The authors are grateful to the Department of Science and Technology (DST) and Council of Scientific and Industrial Research (CSIR) New Delhi, India for financial support.

\section{References}

1. Suzuki, A. Cross-coupling Reactions of Organoboron Compounds with Organic Halides. In Metal-Catalyzed Cross-Coupling Reactions; Diederich, F.; Stang, P. J., Eds.; Wiley-VCH: Weinheim, Germany, 1998; pp 49-89.

2. Tsuji, J. Palladium Reagents and Catalysts: New Perspectives for the 21st Century; Wiley: Chichester, UK, 2004. doi:10.1002/0470021209

3. Negishi, E. Handbook of Organopalladium Chemistry for Organic Synthesis; John Wiley \& Sons, Inc.: New York, 2002.

4. Nicolaou, K. C.; Bulger, P. G.; Sarlah, D. Angew. Chem., Int. Ed. 2005, 44, 4442-4489. doi:10.1002/anie.200500368

5. Miyaura, N.; Suzuki, A. Chem. Rev. 1995, 95, 2457-2483. doi:10.1021/cr00039a007

6. Stanforth, S. P. Tetrahedron 1998, 54, 263-303. doi:10.1016/S0040-4020(97)10233-2

7. Lloyd-Williams, P.; Giralt, E. Chem. Soc. Rev. 2001, 30, 145-157. doi:10.1039/b001971m

8. Hassan, J.; Sévignon, M.; Gozzi, C.; Schulz, E.; Lemaire, M. Chem. Rev. 2002, 102, 1359-1470. doi:10.1021/cr000664r

9. Pu, L. Chem. Rev. 1998, 98, 2405-2494. doi:10.1021/cr970463w

10. Persichini, P. J., III. Curr. Org. Chem. 2003, 7, 1725-1736. doi: $10.2174 / 1385272033486198$

11. Corbet, J.-P.; Mignani, G. Chem. Rev. 2006, 106, 2651-2710. doi:10.1021/cr0505268

And reference therein.
12. Alonso, F.; Beletskaya, I. P.; Yus, M. Tetrahedron 2008, 64, 3047-3101. doi:10.1016/j.tet.2007.12.036 And references therein.

13. Phan, N. T. S.; Van Der Sluys, M.; Jones, C. W. Adv. Synth. Catal. 2006, 348, 609-679. doi:10.1002/adsc.200505473

14. Mino, T.; Shirae, Y.; Sakamoto, M.; Fujita, T. J. Org. Chem. 2005, 70, 2191-2194. doi:10.1021/jo048107i

15. Cui, X.; Zhou, Y.; Wang, N.; Liu, L.; Guo, Q.-X. Tetrahedron Lett. 2007, 48, 163-167. doi:10.1016/j.tetlet.2006.10.124

16. Borhade, S. R.; Waghmode, S. B. Tetrahedron Lett. 2008, 49, 3423-3429. doi:10.1016/j.tetlet.2008.03.109

17. Li, S.; Lin, Y.; Cao, J.; Zhang, S. J. Org. Chem. 2007, 72, 4067-4072. doi:10.1021/jo0626257

18. So, C. M.; Lau, C. P.; Kwong, F. Y. Org. Lett. 2007, 9, 2795-2798. doi:10.1021/ol070898y

19. Marion, N.; Navarro, O.; Mei, J.; Stevens, E. D.; Scott, N. M.; Nolan, S. P. J. Am. Chem. Soc. 2006, 128, 4101-4111. doi:10.1021/ja057704z

20. Hartley, F. R. Supported Metal Complexes: A New Generation of Catalysts; D. Reidel Publishing Company: Dordrecht, Holland, 1985.

21. Garrett, C. E.; Prasad, K. Adv. Synth. Catal. 2004, 346, 889-900. doi:10.1002/adsc.200404071

22. Yin, L.; Liebscher, J. Chem. Rev. 2007, 107, 133-173. doi:10.1021/cr0505674 And references therein.

23. Taylor, R. H.; Felpin, F.-X. Org. Lett. 2007, 9, 2911-2914. doi:10.1021/ol0712733

24. Felpin, F.-X.; Ayad, T.; Mitra, S. Eur. J. Org. Chem. 2006, 2679-2690. doi:10.1002/ejoc.200501004

25. Zhang, Z.; Wang, Z. J. Org. Chem. 2006, 71, 7485-7487. doi:10.1021/jo061179k

26. Yang, Q.; Ma, S.; Li, J.; Xiao, F.; Xiong, H. Chem. Commun. 2006, 2495-2497. doi:10.1039/b605733k

27. Sayah, R.; Glegoła, K.; Framery, E.; Dufaud, V. Adv. Synth. Catal. 2007, 349, 373-381. doi:10.1002/adsc.200600286

28. Wong, H.; Pink, C. J.; Ferreira, F. C.; Livingston, A. G. Green Chem. 2006, 8, 373-379. doi:10.1039/b516778g

29. Köhler, K.; Heidenreich, R. G.; Soomro, S. S.; Pröckl, S. S. Adv. Synth. Catal. 2008, 350, 2930-2936. doi:10.1002/adsc.200800575

30. Jana, S.; Haldar, S.; Koner, S. Tetrahedron Lett. 2009, 50, 4820-4823. doi:10.1016/j.tetlet.2009.05.098

31. Fan, G.; Zou, B.; Cheng, S.; Zheng, L. J. Ind. Eng. Chem. 2010, 16, 220-223. doi:10.1016/j.jiec.2009.08.009

32. Scheuermann, G. M.; Rumi, L.; Steurer, P.; Bannwarth, W.; Mülhaupt, R. M. J. Am. Chem. Soc. 2009, 131, 8262-8270. doi:10.1021/ja901105a

33. Li, C.-J.; Chan, T.-H. Organic Reactions in Aqueous Media; Wiley-Interscience: New York, 1997.

34. Grieco, P. A. Organic Synthesis in Water; Kluwer Academic Publishers: Dordrecht, Holland, 1997.

35. Sheldon, R. A. Green Chem. 2005, 7, 267-278. doi:10.1039/b418069k

36. Beletskaya, I. P.; Cheprakov, A. V. In Handbook of Organopalladium Chemistry for Organic Synthesis; Negishi, E., Ed.; John Wiley \& Sons, Inc.: New York, 2002; Vol. 2, pp 2957-3006.

37. Shaughnessy, K. H. Eur. J. Org. Chem. 2006, 1827-1835. doi:10.1002/ejoc.200500972

38. Shaughnessy, K. H.; Booth, R. S. Org. Lett. 2001, 3, 2757-2759. doi:10.1021/ol0163629 
39. Gelpke, A. E. S.; Veerman, J. J. N.; Goedheijt, M. S.; Kamer, P. C. J.; van Leeuwen, P. W. N. M.; Hiemstra, H. Tetrahedron 1999, 55, 6657-6670. doi:10.1016/S0040-4020(99)00312-9

40. Baruwati, B.; Guin, D.; Manorama, S. V. Org. Lett. 2007, 9, 5377-5380. doi:10.1021/ol702064x

41. Borhade, S. R.; Waghmode, S. B. Indian J. Chem., Sect. B 2008, 47, 1549-1554.

42. McGarvey, G. B.; Owen, D. G. J. Mater. Sci. 1998, 33, 35-40. doi:10.1023/A:1004325108714

43. Palczewska, W. Adv. Catal. 1975, 24, 245-291. doi:10.1016/S0360-0564(08)60484-8

44. Liu, J.-K. Chem. Rev. 2006, 106, 2209-2223. doi:10.1021/cr050248c And references therein.

45. Zhang, C.; Ondeyka, J. G.; Herath, K. B.; Guan, Z.; Collado, J.; Pelaez, F.; Leavitt, P. S.; Gurnett, A.; Nare, B.; Liberator, P.; Singh, S. B. J. Nat. Prod. 2006, 69, 710-712. doi:10.1021/np0505418

46. Roberti, M.; Pizzirani, D.; Recanatini, M.; Simoni, D.; Grimaudo, S.; Di Cristina, A.; Abbadessa, V.; Gebbia, N.; Tolomeo, M. J. Med. Chem. 2006, 49, 3012-3018. doi:10.1021/jm060253o And references therein.

47. Lee, I.-K.; Jung, J.-Y.; Kim, Y.-S.; Rhee, M. H.; Yun, B.-S. Bioorg. Med. Chem. 2009, 17, 4674-4680. doi:10.1016/j.bmc.2009.04.064

48. Ichimura, K. Chem. Rev. 2000, 100, 1847-1874. doi:10.1021/cr980079e

49. Watson, M. D.; Fechtenkötter, A.; Müllen, K. Chem. Rev. 2001, 101, 1267-1300. doi:10.1021/cr990322p

50. Gary, G. W.; Winsor, P. A. Liquid Crystals and Plastic Crystals 1; John Wiley \& Sons, Inc.: New York, 1974.

51. Hall, N. Chem. Commun. 2003, 1-4. doi:10.1039/b210718j

52. Pron, A.; Rannou, P. Prog. Polym. Sci. 2002, 27, 135-190. doi:10.1016/S0079-6700(01)00043-0

53. Rottländer, M.; Knochel, P. J. Org. Chem. 1998, 63, 203-208. doi:10.1021/jo971636k

54. Li, S.; Wei, B.; Low, P. M. N.; Lee, H. K.; Hor, T. S. A.; Xue, F.; Mak, T. C. W. J. Chem. Soc., Dalton Trans. 1997, 1289-1294. doi:10.1039/A607580K

55. Minato, A.; Tamao, K.; Hayashi, T.; Suzuki, K.; Kumada, M. Tetrahedron Lett. 1980, 21, 845-848. doi:10.1016/S0040-4039(00)71521-8

56. Nakada, M.; Miura, C.; Nishiyama, H.; Higashi, F.; Mori, T.; Hirota, M.; Ishii, T. Bull. Chem. Soc. Jpn. 1989, 62, 3122-3126. doi:10.1246/bcsj.62.3122

57. Sinclair, D. J.; Sherburn, M. S. J. Org. Chem. 2005, 70, 3730-3733. doi:10.1021/jo050105q

58. Liu, L.; Zhang, Y.; Xin, B. J. Org. Chem. 2006, 71, 3994-3997. doi:10.1021/jo060122v

59. Miguez, J. M. A.; Adrio, L. A.; Sousa-Pedrares, A.; Vila, J. M.; Hii, K. K. J. Org. Chem. 2007, 72, 7771-7774. doi:10.1021/jo701308b And references therein.

60. Sharif, M.; Zeeshan, M.; Reimann, S.; Villinger, A.; Langer, P. Tetrahedron Lett. 2010, 51, 2810-2812. doi:10.1016/j.tetlet.2010.03.067

61. Paul, S.; Clark, J. H. Green Chem. 2003, 5, 635-638. doi:10.1039/b306097g

62. Wu, K. M.; Huang, C. A.; Peng, K. F.; Chen, C. T. Tetrahedron 2005, 61, 9679-9687. doi:10.1016/j.tet.2005.06.069

\section{License and Terms}

This is an Open Access article under the terms of the Creative Commons Attribution License

(http://creativecommons.org/licenses/by/2.0), which permits unrestricted use, distribution, and reproduction in any medium, provided the original work is properly cited.

The license is subject to the Beilstein Journal of Organic Chemistry terms and conditions:

(http://www.beilstein-journals.org/bjoc)

The definitive version of this article is the electronic one which can be found at:

doi:10.3762/bjoc.7.41 